How to Cite

Kumar, P., \& Mishra, A. (2018). Residents perception analysis of tourism traits and its impact on prospects of Jharkhand

tourism. International Journal of Business, Economics \& Management, 1(1), 1-21. https://doi.org/10.31295/ijbem.v1n1.23

\title{
Residents Perception Analysis of Tourism Traits and Its Impact on Prospects of Jharkhand Tourism
}

\author{
Pranjal Kumar \\ Birla Institute of Technology, Mesra, Ranchi-835 215, India \\ Corresponding author email: pranjalbit@gmail.com \\ Ashutosh Mishra
Birla Institute of Technology, Lalpur Campus, Ranchi-834001, India
}

\begin{abstract}
Jharkhand is popular for tribal culture and uniqueness of its inherent natural beauty attributing significantly on Tourism Industry of Jharkhand. There has been visible change and impact on socio-economic factor because of tourist influx in the Jharkhand state. The inherent beauty and nature has made the state popular for tourism. The attraction towards various important tourist spots revolves mostly within the domestic tourism. The paper attempts to ascertain the impact of tourism traits, like economic Development, Cost of living, Infrastructure Development, Socio-Cultural and the Environment affect through primary data collected from the responses of residents of six dominant tourist circuits of Jharkhand. The respondent's views were ascertained on five-point Likert Scale. The data so collected was subjected to analysis for identifying the impact of various tourism traits on the prospects of Jharkhand Tourism.

Keywords---category, cost of living, economic development, infrastructure development, Jharkhand tourism, sociocultural and the environment.
\end{abstract}

\section{Introduction}

Jharkhand state after registering its identity on 2000 is struggling to portray as a tourist state due to certain policy paralysis and local resistance supported by Maoist and Naxal menace. However one can't ignore after visiting the state that it can cater an important tourist destination comprising all important and popular tourism category. As per the welfare annual plan 2010-2011, Jharkhand has $11.3 \%$ as the Scheduled Castes population and $26.61 \%$ as the Scheduled Tribes population of the total population of 26.90 million. The dominance of tribal culture in the state has been always a matter of study about their culture, craft, language, food etc. The 24 districts of Jharkhand is spread over $74,677 \mathrm{Sq}$. Km with almost 360 peoples residing per square $\mathrm{Km}$.

\section{Review of Literature on Tourism Traits}

Hall (1995), states that the main reason why governments, particularly in developing countries encourage tourism investment is that of the expectations that it will contribute to economic development. It is also argued that tourism should be seen as a means of development in a broader sense. Various economic analysts have also described the broader sense of tourism to mean the potential of the industry to have direct socio-economic impacts on destination regions. This issue is made clear by Douglas (1987), who states that development should not only refer to economic matters but should encompass social, economic, environmental and ethical considerations such that its measurement may incorporate indicators of poverty, unemployment, inequality, and self-reliance.

The economic impacts reported in the study of Guam Visitors Bureau (2007); (Christoper, 2007). The study represented Tourism on Guam generated \$140.5 million in local taxes in 2005. Payroll taxes, income taxes, the gross receipts tax, and the hotel tax make up the majority of the taxes received. It has also added if tourism did not exist in 
each of the 38,769 households on Guam would have to pay an additional $\$ 2,577$ in taxes in order to maintain the current level of tax receipts. While the largest economic impacts will be to the core tourism businesses like hotels and restaurants, a report has illustrated the fact that certain industries not directly involved in travel and tourism saw significant economic benefits, sometimes larger than industries directly linked to tourism in Guam; like FIRE sector shows an economic impact similar to the food and beverage sector.

Sharma (1995), has prescribed the following guidelines for establishing monitoring parameters for assessing the impacts of tourism.

(1) Parameters for monitoring socio-cultural impacts like (demographic changes, social mobility, social cohesion, attitudes and values, the practice of cultural traditions and rituals and cultural heritage).

(2) Parameters for monitoring Economic impacts (contribution to cash income and livelihood options, land ownership, asset formation, wage rates, the prevalence of child labor, reinvestment of tourism earnings in the locality and qualitative perception of linkages within the productive sectors resulting from tourism).

Axel (1998), has defined the term social indicators and has given the framework of indicators. Within the heading of Socio-economic indicators, Socio-cultural indicators, Socio-spatial indicators and Socio-ecological indicators, the framework has simplified the task by dividing it as an area of concern and Performance Indicators.

Economic development and tourism development often occur in a parallel fashion. Robinson (1996), distinguished five stages of economic development, which Cooper et al., (1998), linked to certain levels of tourism development. Romila (2004), has examined economic impacts of tourism according to some key economic areas; such as employment, income generation, tax generation and induced investment due to the movement and concentration of people in popular tourist areas.

Lama (2006), has given more weight on contribution of tourism in women development. He stated in his literature; Tourism has more effects on women's lives in destination communities. The lack of gender sensitivity in government tourism development strategies and socioeconomic inhibitions of women perpetuated by society have constrained women from more fully benefiting from opportunities availed by mountain tourism in Nepal. Chakravarti (2002), in his research article, "Tourism and the socio-cultural environment- a study of West Bengal" has given an analysis of effects of tourism on socio-cultural environment in the state.

Goodwin (2006), has concluded in his research paper that given the diversity of approaches and of the target beneficiaries, no single methodology can be used to measure all of them. Agencies, funders and practitioners need to evolve ways of transparently measuring the beneficiary level impact of initiatives, and of reporting these to the both to funders and other stakeholders engaged in the particular initiatives- funders and agencies should demand it, practitioners should accept that it is expected of them as good practice, and recognise that only this way can best practice can be identified and the effectiveness of the interventions be maximised. This paper has presented brief review \& critique of current ways of measuring and reporting the economic impacts of tourism on national economies in the context of changing policy environment of tourism \& development. He has specifically mentioned that the tourism satellite account and multipliers are unable to measure the impact of tourism on local economic development in general and poverty reduction in particular.

Brida (2011), have provided a planner in their study paper to those people concerned about, or opposed to, tourism planning and development in their communities. They have used PCA to group attitudes and perceptions variables to obtain uncorrelated factors. This study also presented models that explain how the hosts' opinions about tourism influence factors representing tourism development policies. They have defined the roles of public and private sectors in the context of sustainable tourism planning and development; their findings have suggested the need for a more cohesive interaction amongst implementing stakeholders, in the consithe deration of sustainable development. According to their study the economic, social and environmental aspects of sustainable development must include the collective interests of all stakeholders. The public sector must participate in the education and preparation of stakeholders in using data, exercising. They have stressed to collect more information about the attitude of local residents towards the possibility to implement tourism, using again the instrument of public discussions or workshops with experts.

Styns (1997), has contributed to decide reliable study approaches and to design proper assessment tools to measure economic impact of tourism with special reference to economic concept \& methods. He added that the variety of methods from a general framework to mathematical methods; are used to estimate tourism economic impacts. He pointed that the studies vary extensively in quality and accuracy, as well as which aspects of tourism are included. According to his view, technical reports are often are filled with economic terms and methods that noneconomists do not understand. On the other hand, media coverage of these studies tends to oversimplify and frequently misinterpret the results, leaving decision makers and the general public with sometimes distorted and 
incomplete understanding of tourism economic effects. He has discussed the suitability of input-output model and presented different kinds of multipliers reflecting which secondary effects are included and which measure of economic activity used like sales, income or employment. Stynes and Propst have developed a fairly complete microcomputer-based system for estimating economic impacts of recreation and tourism. MI-REC spreadsheets estimate visitor spending within up to 33 categories based on the number and types of visitors attracted to an area. Spending is then bridged to the IMPLAN model sectors to estimate direct, indirect and induced effects in terms of sales, income, and employment. Users may estimate spending via visitor surveys or use the MIREC database of spending profiles, compiled from previous studies.

Chris cooper (2005), in their book "Tourism - Principles and Practice" suggest international tourism demand can be assessed by three factors as (i) Volume statistics - the total tourists might's (ii) Value (Expenditure) statistics total visitor expenditure and (iii) Visitor Profile Statistics - related to the visitor and those of the visit.

Chris Cooper also makes scientific suggestions for assessing domestic tourism demand. He presents four factors that are used to measure domestic tourism demand as (i) Household Surveys - using a questionnaire to see the travel pattern of the residents. (ii) En Route Surveys - surveys of travelers during the course of their journey, by using questionnaire. (iii) Destination surveys - conducted at popular tourist destinations or in areas where there are high levels of tourist activity. (iv) Survey of suppliers - conducted on suppliers of tourism services as hotels and airlines.

Kumar (1996), in the book, "Tourism and Economic Development" presents the status of tourism potential of Himachal Pradesh as an instrument of economic development in the state. The text clearly states how the government can partner with the private entrepreneurs to promote the cause of tourism as well as boost the economy of the locality. These suggestions are taken by the researcher to investigate and continue his work.

Davidson (1993), in his book, "Tourism" presents the basic structure of tourism in England and details its development and the impact of it on the nation. He cites various cases to drive home the point that tourism creates wonderful International understanding among nations and especially between the European and Asian regions. Entrepreneurs should develop this sense of international relations to able to deal successfully with their overseas clients.

Bull (1995), in, "The Economics of Travel and Tourism" discusses the economic importance of Tourism's contribution to Gross Domestic Product (GDP) of a Nation. He suggests ways and means improve the role of tourism in the aspect of Balance of Payment of a Nation. The literature gave important clues on the national economy building capacity the tourism entrepreneurs possess.

A study carried out by Sharma (1975), explored the emerging patterns of growth of entrepreneurship, their performance and problems in the state of Uttar Pradesh. He also analyzed the effect of socioeconomic background of entrepreneurs and their performance in the theoretical framework provided by Weber, Mc-Cleland, and others.

\section{Important Tourist Circuits of Jharkhand}

The paper identified following tourist circuits as an important spot based on its popularity and Tourists categories:

a) Ranchi-Hazaribagh-Tilaiya

b) Daltenganj-Mahuadandh-Netarhat-Ranchi

c) Ranchi-Bundu-Jamshedpur

d) Deoghar

e) Dhanbad

f) Saranda

\section{a. Ranchi}

Tagore Hill: The name Tagore hill which is 300 feet in height is a place to visit. The tourist importance of the place lies in the fact that Rabindranath Tagore has resided at the hilltop and documented his thoughts.

Hundru Falls: This is one of the important picnic spots of the local residents which is about $28 \mathrm{~km}$ far from the state capital. It is dangerous to ploy visit at hundred falls during the rainy season but it is summers delight with sparkling water falling from the height of 320 feet with tremendous noise which makes people relax spending hours.

Dasham Falls: The most populous falls which could be in the mind of each and every resident whenever there is mention of falls to visit? The tourist visiting the place could feel lethargic and relaxed with the surrounding scenic beauty. It is approachable from the state capital with just $40 \mathrm{kms}$ away. The river Kanchi flows and falls from the height of 144 feet making the pool of water beautiful and prompts the swimmers to jump into the water to feel its freshness. However off late due to certain causality, the fall has been restricted to enter into the water pool. 
Jonha Falls: The approach road towards the fall is adventurous and the spot is $40 \mathrm{~km}$ away from the Ranchi town. There is rest house at the spot, tourist can stay and relax and also worship the famous Gautam Budha temple. Gautamdhara is another name of the Jonha falls because of the manifestation of Gautam Budha temple.

Hirni Falls: The most scenic beauty falls is the Hirni falls as it is located within the dense forest Hirni. The bounty of nature's paradise makes the falls an interesting place of tourist destination which is about $70 \mathrm{Km}$ from the Ranchi township. The visit to the place is wonderful and their sensations are nourished in the peaceful environment.

Ranchi Hill: The hill is at the height of 2140 feet and attracts the tourist to have a panoramic view of the entire city. There is a temple of Lord Shiva at the top of the hill. The hill serves the multiple purposes of religious and icon tourism. During the month of August, devotees come to offer their praying considering the temple to be a replica of the Baba Dham.

Jagannathpur Temple: It is also a replica of famous Jagannath temple of Puri in Orissa. All the rituals related to the temple are similar in customs followed at Jagannathpur. The Rat yatra in the month of July is very famous and the fair of the festive season attracts a huge crowd from the entire districts of the state. The temple was founded in the year 1691. The exclusivity of the temple is that it is located at the hilltop in HEC township area with a distance of approximately $10 \mathrm{Kms}$ from the township.

Nakshatra Van: This is newly developed concept initiated by the state government which is a sort of nursery of 27 varieties of medicinal plants correlating with 27 planets of the universe. To increase the interest the Van is fortified with all amenities having a musical fountain as a special fascination.

Mc Cluskieganje: A sleepy small hamlet $67 \mathrm{Km}$ from Ranchi on State Highway 47. With a total area of 35 sq. $\mathrm{km}$, this place was popular with Anglo Indian community. The name evokes nostalgia and one gradually discovers that the place is amidst the green forest. At the height of $2140 \mathrm{ft}$, the weather is remarkably recreating for the tourists. Peak temperature is of $35^{\circ} \mathrm{C}$ during summer otherwise winter is a most charming season at this place. Visitors come here to spend their time in leisure, earn peace and rejuvenate themselves.

Crocodile Park: $32 \mathrm{Km}$ from Ranchi on Ranchi-Hazaribagh route. There are 20 muggars (2 old, 10 young \& 8 children). Some 5 muggars were shifted to Patna Zoological Park in 1999 from this place. Best food for these muggars is Fish \& Meat. On an average $15 \mathrm{Kgs}$ of mutton is served to the Muggars. Bheda River is base for Muggars; they freely reside in the water and at times come out in the plains also. This creates panic in the local inhabitants as well as tourists also.

Netarhat: It's a natural paradise which is unrivaled with a combination of all beauty coinciding with all natural greenery of dense forest, cool temperature because it is 37000 feet above the sea level. Probably it is believed that this place was the summer camp of British and they have called it to the heart of nature when the words combined become Neterhat. It is $156 \mathrm{Km}$ away from the state capital. The place grows more spectacular during the full moon period. The tourist visiting feels themselves to be placed somewhere out of this world.

Gonda Hill \& Rock Graden: It is a beautiful artifact for a pleasure trip and a good place of recreation for the local residents which is located at the Gonda Hill top. Lots of basic amenities are available to meet the requirement of the visitors. The night view of the entire township is amazing form the Rock Garden. Kanke Dam is at the foot of the hill which adds to the magnificence of the place.

Sun Temple: It is also a replica of famous sun temple at Bhubaneswar. It is $39 \mathrm{Kms}$ far from the Ranchi town another beautiful picnic spot. The visitors feel the dual delight of worship and fauna.

Amreshwar Dham: Akin to Baba Dham, Amreshwer Dham is also famous for the pilgrimage of religious purpose. There are many temples of Hindu Gods and Goddesses. It is located in the astronomic beauty of Angrabadi.

Ranchi Lake: This is centrally located in the heart of the town and is being developed for the tourism purpose. The lake is quite deep and boating facility is available. However, there needs to be a lot of measures to be taken to make more attractive, safe and secure. The history says that the lake was exhumed by Col. Onsely, a British Agent in 1842 .

Birsa Jaivik Udyan: Birsa Jaivik Udyan, This Zoological garden is located at Ormmanjhi about $16 \mathrm{~km}$ from Ranchi. The total stretch is of about $5 \mathrm{Kms}$ circular in nature with varieties of animal species. It is the most populous Zoo of the state.

Panch Gagh Falls: It is about $6 \mathrm{Kms}$ from Khunti where five river streams combined in one dharas which falls form decent height referred to be Panch Gagh.

Deer Park: It is Located at Kalamati $24 \mathrm{Km}$ from Ranchi on Ranchi-Chaibasa Road. Its foundation was laid in 1981 and Mochiram Munda did formal opening in 987. The park is spread in the 54-Acre area. There are 214 
Deer in the park out of this 48 are sambhar and 166 are cheetal. Visitor influx during the lean period is $25-35 /$ day and during peak, it is 50-60/day.

\section{b. Jamshedpur}

Jubilee Park: The Park as the name jubilee, which means anniversary; lies in the fact that it hosts the birth anniversary celebration of the father of industrialization Jamshedji Tata on $3^{\text {rd }}$ of March every year. The park was constructed as a tribute to Jamshedji Tata and was open to the public after the mark of the golden jubilee year. The management was handed to JUSCO a part of the steel company. The park is developed in the footstep of Vrindavan gardens of Bangalore. The park is a binge of 225 acres with sub-sectional parks catering to the tourist delight of all ages. The park consists of Mughal garden a replica of Mughal garden in Kashmir. There was no stone unturned to make the park respectable and attractive with state of the art facility. It will take almost 2-3 days to reconnoiter the gratification hidden in the park offering different tourist activity.

Dimna Lake: The lake is $13 \mathrm{Kms}$ far from Jamshedpur which is delimited by flowers. The lake flows at bottom of Dalma Hills. It is an excellent picnic spot for the local residents of the city.

Dalma Wild Life Sanctuary: A dense forests binge 195 sq. kms. It is one of the famous Wild Life sanctuaries where one can enjoy roaring tigers, wise elephants, deers, bears and all other herbivorous and carnivorous animals. The gradients of Dalma attracts trekking sports for the tourist who wants to enjoy adventure tourism.

Hudco Lake: A snuggle in the charming and hilly topography of Telco Society, the lake is a wonderful haven for those keen on being in nature's- lap' inside the city confines.

Keenan Stadium: It is a lush green internationally acclaimed stadium which has hosted several one-day international games and has been witnessed by many players of international teams.

JRD Tata Sports Complex and Gliding and Flying Clubs: These are the international standard football ground as well as other sports like handball, volleyball, hockey and table tennis and people interested if flying and gliding activities. The reason being that Ratan Tata the descendant of the Jamshedji family himself has made the record in flying his charted plane as one of its hobbies. The sports complex is equipped with the state-of-the-art gymnasium.

Tata Steel Zoological Park: The park is the reservoir of natural habitat with a range of flowers and fauna. The park witnesses the itinerant birds during the winter season. There is a beautiful lake and Machaan Resturant.

\section{c. Deoghar}

Baidhnath Temple: The history of temple says that it was established in the year 1596 when a pursuer named Baiju, revealed the misplaced lingam. After its discovery, the ling gots its historical importance as there is a strong believes that wishes come true after worshiping the lingam. It is located about $1 \mathrm{KM}$ from the railway station. In Shravan month, lacs of devotees come on foot from all over India to offer the holy water of river Ganga (Sultanganj about $100 \mathrm{~km}$. far from Babadham).

Naulakha Temple: The is a glorious temple of God and Goddesses Radha-Krishna located in the suburb of the Deogarh town. The temple has beautiful carving and worth visiting to observe the advanced architecture of the ancient period. The temple was constructed by one of the followers of Balanand Brahmachari, Rani Charushila, the queen of Pathuriaghat of Deoghar.

Tapovan: It is placed famous for various hills, fissures and temples built at the hilltop. The place is popular for performing meditation and in the ancient time's various rishis and munis used to meditate at the place to attain enlightenment. Because of the purpose, the place became famous as Tapovan. It is approximately 8-9 Kms from the Deoghar town.

Rikhia Dham: This world famous Yogashram of "Shivanand Math Yogacharya" continues to serve the people and provides new life to the needy is situated about $9 \mathrm{kms}$ away from Deoghar in the northern part of the town. This Yogashram is a new branch of the world famous "Shivanand Math of Munghyi" Every year on the eve of "Shri Krishnajanamastmi" and "Sita Kalyanam" a "Shatchandi Mahayagya" is organized in which innumerable devotees from this country and abroad take part to in it.

Trikuti Hill: Trikut Parbat is $18 \mathrm{~km}$ from Edgar railway station. Three peaks of these hills are named: one is Brahma second is Vishnu and the third is Mahesh war. Hills are spread in an area of 2110.28 acres and highest peak is 2470 feet. There is a temple of Lord Maheshwar on the highest peak. Top of the hills is plane and is called "Sita Chatal". There is a fall in front of Maharishi Dayananda Ashram named "Guru Sidhu Fall". "Siddha Brahmachari Bombom Baba" built this fall. Devi Durga temple was built in 1933. Every year Chaitra Durga Puja is organized at this place. During this period local and outside Jharkhand people visit this place to participate in 
the puja. It is situated $13 \mathrm{~km}$ away from Deoghar on the way to Dumka. There are three main peaks on the hill which is why it is called Trikutachal. The height of this hill is 2,470 feet $(750 \mathrm{~m})$. There is also a temple of Shiva at this place known as Trikutachal Mahadeva Temple. It is the mouth of river Mayurakshi. There is also an altar of the goddess of Trishuli. It is an attractive place with a cool stream flowing. Now, this has Jharkhand's first ropeway.

Satsang Ashram: It is $2 \mathrm{~km}$ from Baidynath Dham mandir. There is a railway halt inside the ashram and local train's halts at this place. Public transport is available for the ashram. The Ashram is spread over approx. 7 acre of land. The ashram is most respected place in the pilgrimage city of Edgar. Sri Thakur Anukul Chandra established this ashram on 1st September 1946. Presently varied institutions are operational in Ashram and have more than 2000 branches across the world. Satsangha computer center: With the support of Barda computer networking institute.

Nandan Hills: Nandan Pahar is $3 \mathrm{~km}$ away from Baidyanath Dham railway station. Temple of Lord Shiva, Devi Parvati, Lord Ganesh, and Kartik are situated at the hilltop. View of sunrise \& sunset from the hilltop is panoramic. Water tanks at hilltop supply drinking water to Edgar and this is connected to Darowa River. A children park is built near the hill, this is perceived as a real park by the tourists. Rides at the park excite the children visiting there. Food \& other amenities are available at the spot.

Nav Durga Temple: Nav Durga Mandir is $2 \mathrm{~km}$ from Baidyanath Dham railway station. The temple is also known as "Debsangha". Param Gyanee Swami Narendranath Brahmachari built this temple. Shrine "Nabadurga Murti" is the highly regarded and popular attraction for the visitors. Every year in Durga Puja Mandir committee arrange puja of "Nabadurga". Lakhs of pilgrimage visit the temple during this period. Nav Durga Mandir Committee performs varied social work. They have built a school, dispensary to serve the poor people every year in Durga Puja they arrange food and cloth to distribute them to poor at free of cost. Visitors are not only from India but international tourist also takes out their time to visit this temple.

Ramakrishna Mission Ashram: It is one and a half kilometers from Edgar station. It was established in 1922 with an area of 7 Bigha. There are two large playgrounds and an exquisite garden. Mandir is decorated with the photo of Ramakrishna Paramhansa, Saroda ma \& Vivekananda. Dr. A.K. Kidwai in 1996, the former Governor of Bihar, inaugurated a bronze statue of Swami Vivekananda. The ashram provides livelihood to hundreds of local inhabitants through its various activities.

\section{d. Dhanbad}

Maithon Dam: $52 \mathrm{~km}$ from Dhanbad, It is situated at the border of Jharkhand and West Bengal. The lake is spread in an area of $65 \mathrm{~km}$. Total dam area is $2 \mathrm{~km}$ but a main portion (means log gate portion) is $1 \mathrm{~km}$. The Jawaharlal Nehru, Prime Minister of India, inaugurated it in 1949. Maithon can also be termed as "Mother's Adobe". Deer Park \& Bird sanctuary adds the exquisite look to this spot. It is on the Barakar River. Endless beauty of nature and construction of Dam attracts people from all over the country. This is the biggest reservoir in Damodar Valley Corporation and is famous for its underground power station. This was first of its kind in South East Asia.

Kalyaneshwari Temple: This temple is of Goddesses Maa Kalyaneshwari. A large number of Hindu devotees worship the temple for their 'Kalyan'; fulfilling their desire and necessity, health and wealth. The temple is located $46 \mathrm{Kms}$ from the Dhanbad town. The name Maithan is believed to be derivative of the popularity and power of the deity termed as Mai-Ka-Than meaning Abode of the Goddess.

Topchanchi Lake: $35 \mathrm{~km}$ from Botarned Bus stand of Dhanbad. British Authorities has excavated the Lake in 1924. The British made a Ban Bungalow in 1918 for staying of engineers who supervise the work of lake. Area of the lake is about $7 \mathrm{~km}$ and is covered by tar road. A dam is built on the lake to supply the water to Dhanbad, Katrar, and Jhariya. The scenic beauty and hillside view of the lake is an incomparable and major attraction for the visitors. Wild animals like cheetah, deer, elephant and many others visit the lake during the night. This attracts the adventure as well as wildlife tourists to the spot. Two bungalows are there for the tourists one of BSTDC and another is private. Restaurants are available in surrounding proximity of the lake. Tourists enjoy the beauty of lake while enjoying food in restaurants. The local authority facilitates photography. The varied medium of communication is available at the spot.

Indian School Of Mines: Indian School of Mines (ISM) is one of the best mining institutions of the country. The alumni of the institute have created history and discovered areas of fuel reservoir adding to the energy security of the country. The year of establishment of the institute is 1926 in the footsteps of Royal School of Mines. Presently it has been approved to be awarded IIT status. Primarily the institute is known for mining engineering 
but other branches of engineering and management disciplines are established. The institute has got the hostel facility.

Panchet Dam: Constructed on Damodar River, it is $32 \mathrm{~km}$ from Kumardumbhi and $45 \mathrm{~km}$ from Asansol. This dam is similar to Maithon Dam and situated on the Border of West Bengal and Jharkhand. Jawaharlal Nehru inaugurated it in 1949. Total dam area $1.5 \mathrm{~km}$ and the main portion (i.e. gate portion) is $1 / 2 \mathrm{~km}$. No. of gates is six. The beauty of the lake and small tiles are the main attraction. A Hydel station is constructed against the background of Panchet Hill in the eastern side of the Dam.

Shakti Mandir: It is the famous temple of Goddess Durga symbol of Shakti, attracts lots of devotees.

Sindri: BIT Sindri a famous engineering institute and the place is famous for the industrialization of chemical and fertilizer factories. The location is approximately $30 \mathrm{Kms}$ from the Dhanbad Town at coastal region of Damodar River.

Panera: The village is famous due to its historical facts related to the great epic of Mahabharata. It is believed that Pandavas expended stay of their exile in walloping at this place. The village contains an ancient temple of Lord Shiva known as Pandeweshar Mahadev.

Chati Gobindpur, Meva, and Gopalpur: These are the villages known for their ancient heritage. They are documented in the history of the remnants of Mauryan Dynasty of emperor Ashoka and Sher Shah. In Meva and Gopalpur a stone idol of Ashoka is sited.

The Majestic Valinda Falls: One of the most ancient falls in West Jhariya; it is about $20 \mathrm{~km}$ from Dhanbad. This falls situated on Vaitinda River. The height of the falls is 350ft. meter from the ground level. Temple of Lord Shiva is built on the top of the falls. The front side of the falls is Aurangabad and the backside is Vardhao village. On the way of Putki-Vatinda, there is a coalmine named "Munide" of Central Coalfields Limited.

\section{e. Hazaribagh}

Hazaribagh Wildlife Sanctuary: This sanctuary is situated on Hazaribagh- Barahi Road, 19 km from Hazaribagh. This was notified in 1976 \& enjoys a good number of tourist inflow every year. Total forest area is 186.25 sq. km of which $70 \mathrm{sq} . \mathrm{km}$ is identified as a tourist area. Principal animals are Tiger, Panther, Wild Boar, Nilgai, and Sambhar etc. There are 10-watchtowers in the sanctuary that gives a panoramic view of the wildlife.

RajrappaTemple: Rajrappa is situated at the convergence of river Damodar and Bhairavi, (popularly known as Bhera) $80 \mathrm{~km}$ from Ranchi. (Ranchi- Ramgarh-Rajrappa). The headless temple of Goddess Chhinnamastika stands on the body of Kamdeo and Rati in Lotus bed. This temple is supposed to be very sacred. It is a very old one and its architectural design resembles the design of temples of Tantrik importance. It is pronounced that Viswakarma himself has built this temple. A number of attractive temples have been building around the main temple. A large number of pilgrimages come here throughout the year, particularly from Bihar, Jharkhand and West Bengal. Various rituals are performed here for the good cause. The presumption is very famous that first worship at this place multiplies the luck. "BALI" (goats head is offered to Maa Chhinnamastika) performed by devotees either for completion of any wish or on completion of any wish. On 14th of January (Makar Sankranti) a special religious fair is organized visitors are in lacs for this. A similar fair is also organized on Vijayadashmi.

Canary Hill: $5 \mathrm{~km}$ from the city heart. This is a recreation spot and one can have a view of Hazaribagh city from a hilltop. Hill infrastructure is compatible with Adventure sports i.e. trek, rock-climbing etc. in the winter season. Trekking facility is available for the visitors in the winter season.

Hazaribagh Lake: Hazaribagh Lake is a beautiful naturally oriented lake which attracts lots of visitors in and around districts to spend hours for recreation as well as enjoying a family picnic.

Telaiya Dam: This is small hamlet located at $67 \mathrm{~km}$ from Hazaribagh. This place is known for Sanik School and Damodar Valley Corporation (DVC) in tandem with its natural resources. Tilaiya besides being a recreation spot has always been admired for its climate \& scenic beauty. This is well connected with Road from Hazaribagh. Public Transport is available from Ranchi as well as Hazaribagh for this place. Nearest railway, the station is Koderma a major station on Howarh-Delhi Grand Chord line.

Surajkund: It is about $65 \mathrm{Kms}$ from the district and famous for Kund which are having springs of blistering water.

Urwan Tourist Complex: It is a complex developed by JSTDC primarily for the motive for recreation. It is 62 $\mathrm{Km}$ far from the Hazaribagh town. One can spend time for hours and enjoy boating as cruise tourism along with the fun of water sports.

Salpharni Dam: It is located at $18 \mathrm{~km}$ from Hazaribagh. A good number of birds migrates in winter \& rainy season that adds flare to this spot. 
f. Saranda

It is located in the West Singbhum District in the State. This place is Nature paradise where nature reigns supreme. In Ho Language, it means "Land of 700 Hills". Exciting and colorful flora and fauna present. Sal is the most dominating tree species. Rare herbs, shrubs also feature amongst the floral species. Mammals, Birds, and Reptiles feature amongst the fauna. Has a wonderful array of Natural Resources (Kiriburu - Thalkobad Ligirda Swamp - Toybo Falls - Loyall's View) as well as Spiritual Delights (the likes of Sameej Ashram - Mahadev Sal - Maa Giri Rajeshwari).

\section{Research Method}

Responses of 50 residents' from the five districts Ranchi, Jamshedpur, Hazaribagh, Deoghar, Dhanbad and Saranda totaling to 300 responses were taken on the basis of the convenient non-probability sampling method. These five districts are imperative from the perspective of various types of tourism attracting the domestic as well as foreign tourists. The districts names are Ranchi, Jamshedpur, Hazaribagh, Deoghar, Dhanbad, and Saranda. The analysis of the data is done considering the prospects of Jharkhand tourism as Depended Variable over tourism traits which are Economic Development, Cost of living; Infrastructure Development; Socio-Cultural and the Environment termed to be Independent Variables. The variables under each construct were derived through literature survey, interviews and discussion with the residents belonging to the above mentioned important tourist circuits. The chi-square test was applied via cross-tab for the test of independence. One way ANOVA, Correlation \& Regression followed by DurbinWatson test for Autocorrelation. Further VIF test was conducted to explore the multicollinearity amongst the identified tourism traits as Independent Variable and t-test application for measuring the significance of Regression Parameters. The entire above mentioned statistical test was applied to find the impact of tourism traits on prospects of Jharkhand tourism.

\section{Results and Analysis}

Table 1

Identification of Tourism Traits

Authors \& Year
Hall, C. (1995).
Douglas, P. (1987).
Christoper, P. (2007).
Sharma, P. (1995).
Axel, S. (1998).
Robinson, H. (1996).
Romila, C. (2004).
Lama, B. \&. (2006).

Goodwin, H. (2006).

Name of the Topic
Tourism, Ecotourism and
Protected Areas.
Tourism Today- "A
Geographical Analysis".
Guam Tourism Economic
Impact. Eddystone: Guam
Visitors Bureau
Tourism for Local Community
Development in Mountain
Areas.
'Social Indicators of Sustainable
Tourism'.
Geography of Tourism.

Economics of Tourism \&

Development.

Community Bases Tourism for Conservation \& Women's

Development.

Measuring \& Reporting the impact of tourism on Poverty.

\author{
Tourism Traits \\ Economic Development, Socio \\ Cultural Impact. \\ Economic Development, Socio \\ Cultural and Environmental \\ Development Impact. \\ Economic Development \\ Impacts.
}

Economic Development, Socio

Cultural Impact.

Socio-Cultural Impact

Economic Development

Impacts.

Cost of living and Infrastructure development impacts.

Socio-cultural and Environment

Development impacts

Cost of living and Economic

Development Impacts. 


\begin{tabular}{|c|c|c|}
\hline Authors \& Year & Name of the Topic & Tourism Traits \\
\hline Brida, J. (2011). & $\begin{array}{l}\text { Tourism influence factors } \\
\text { representing tourism } \\
\text { development policies. }\end{array}$ & $\begin{array}{l}\text { Economic Development, Socio } \\
\text { Cultural and Environmental } \\
\text { Development Impact. }\end{array}$ \\
\hline Styns, P. \&. (1997). & $\begin{array}{l}\text { Tourism-Economic } \\
\text { Approaches \& Methods. }\end{array}$ & $\begin{array}{l}\text { Cost of living and Economic } \\
\text { Development Impacts. }\end{array}$ \\
\hline Chris Cooper, J. F. (2005). & $\begin{array}{l}\text { Tourism-Principles and } \\
\text { Practice. }\end{array}$ & Cost of living impacts. \\
\hline Kumar, N. (1996). & $\begin{array}{l}\text { Tourism and Economic } \\
\text { Development. }\end{array}$ & $\begin{array}{l}\text { Economic Development and } \\
\text { Infrastructure development } \\
\text { impacts. }\end{array}$ \\
\hline Davidson, R. (1993). & Tourism. & $\begin{array}{l}\text { Economic Development and } \\
\text { Cost of living impacts. }\end{array}$ \\
\hline Bull, A. (1995). & $\begin{array}{l}\text { The economics of Travel and } \\
\text { Tourism. }\end{array}$ & $\begin{array}{l}\text { Economic Development, } \\
\text { Infrastructure Development and } \\
\text { Cost of living impacts. }\end{array}$ \\
\hline Sharma, K. L. (1975). & $\begin{array}{l}\text { Entrepreneurial Performance in } \\
\text { Role Perspective. }\end{array}$ & $\begin{array}{l}\text { Socio-cultural and Environment } \\
\text { Development impacts }\end{array}$ \\
\hline
\end{tabular}

One way ANOVA Test has been conducted between prospects of Jharkhand Tourism and different Districts which is represented in Table 2.

Table 2

ANOVA Table

\begin{tabular}{|c|c|c|c|c|c|c|}
\hline & & $\begin{array}{l}\text { Sum of } \\
\text { Squares }\end{array}$ & $\mathrm{df}$ & $\begin{array}{l}\text { Mean } \\
\text { Square }\end{array}$ & $\mathrm{F}$ & Sig. \\
\hline \multirow{3}{*}{$\begin{array}{l}\text { Prospects of Jharkhand } \\
\text { Tourist * District }\end{array}$} & Between Groups (Combined) & 31.000 & 5 & 6.200 & 14.700 & .000 \\
\hline & Within Groups & 124.000 & 294 & .422 & & \\
\hline & Total & 155.000 & 299 & & & \\
\hline
\end{tabular}

As the value of $\mathrm{p}$ in the above ANOVA table is less than 0.05, so we conclude that prospects of Jharkhand Tourism are significantly different in various districts of Jharkhand at 5\% significance level.

Table 3

Correlations

\begin{tabular}{|c|c|c|c|c|c|c|c|}
\hline & & $\begin{array}{l}\text { Prospects of } \\
\text { Jharkhand } \\
\text { Tourist }\end{array}$ & $\begin{array}{l}\text { Economic } \\
\text { Development }\end{array}$ & $\begin{array}{l}\text { Socio- } \\
\text { Cultural }\end{array}$ & $\begin{array}{l}\text { Cost of } \\
\text { Living }\end{array}$ & $\begin{array}{l}\text { Infrastructure } \\
\text { Development }\end{array}$ & $\begin{array}{l}\text { Environmental } \\
\text { Quality }\end{array}$ \\
\hline \multirow{4}{*}{$\begin{array}{l}\text { Prospects of } \\
\text { Jharkhand } \\
\text { Tourist }\end{array}$} & $\begin{array}{l}\text { Pearson } \\
\text { Correlation }\end{array}$ & 1 & $.850^{* *}$ & $.544^{* *}$ & $.451^{* *}$ & $.853^{* *}$ & $.201^{* *}$ \\
\hline & Sig. (2-tailed) & & .000 & .000 & .000 & .000 & .000 \\
\hline & $\mathrm{N}$ & 300 & 300 & 300 & 300 & 300 & 300 \\
\hline & Pearson & $.850^{* *}$ & 1 & $.492^{* * *}$ & $.294^{* * *}$ & $.746^{* *}$ & $.234^{* *}$ \\
\hline Economic & Correlation & & & & & & \\
\hline \multirow[t]{3}{*}{ Development } & Sig. (2-tailed) & .000 & & .000 & .000 & .000 & .000 \\
\hline & $\mathrm{N}$ & 300 & 300 & 300 & 300 & 300 & 300 \\
\hline & Pearson & $.544^{* *}$ & $.492^{* *}$ & 1 & $.430^{* *}$ & $.498^{* *}$ & $.178^{* *}$ \\
\hline \multirow{4}{*}{ Socio Cultural } & Correlation & & & & & & \\
\hline & Sig. (2-tailed) & .000 & .000 & & .000 & .000 & .002 \\
\hline & $\mathrm{N}$ & 300 & 300 & 300 & 300 & 300 & 300 \\
\hline & Pearson & $.451^{* * *}$ & $.294^{* *}$ & $.430^{* *}$ & 1 & $.552^{* *}$ & $.225^{* *}$ \\
\hline \multirow{3}{*}{ Cost of Living } & Correlation & & & & & & \\
\hline & Sig. (2-tailed) & .000 & .000 & .000 & & .000 & .000 \\
\hline & $\mathrm{N}$ & 300 & 300 & 300 & 300 & 300 & 300 \\
\hline
\end{tabular}


Table 3

Correlations

\begin{tabular}{|c|c|c|c|c|c|c|c|}
\hline & & $\begin{array}{l}\text { Prospects of } \\
\text { Jharkhand } \\
\text { Tourist }\end{array}$ & $\begin{array}{l}\text { Economic } \\
\text { Development }\end{array}$ & $\begin{array}{l}\text { Socio- } \\
\text { Cultural }\end{array}$ & $\begin{array}{l}\text { Cost of } \\
\text { Living }\end{array}$ & $\begin{array}{l}\text { Infrastructure } \\
\text { Development }\end{array}$ & $\begin{array}{l}\text { Environmental } \\
\text { Quality }\end{array}$ \\
\hline & Pearson & $.853^{\text {** }}$ & $.746^{* *}$ & $.498^{* * *}$ & $.552^{* * *}$ & 1 & $.179^{* *}$ \\
\hline Infrastructure & Correlation & & & & & & \\
\hline \multirow[t]{3}{*}{ Development } & Sig. (2-tailed) & .000 & .000 & .000 & .000 & & .002 \\
\hline & $\mathrm{N}$ & 300 & 300 & 300 & 300 & 300 & 300 \\
\hline & Pearson & $.201^{* *}$ & $.234^{* *}$ & $.178^{* *}$ & $.225^{* *}$ & $.179^{\text {** }}$ & 1 \\
\hline \multirow{3}{*}{ Quality } & Correlation & & & & & & \\
\hline & Sig. (2-tailed) & .000 & .000 & .002 & .000 & .002 & \\
\hline & $\mathrm{N}$ & 300 & 300 & 300 & 300 & 300 & 300 \\
\hline
\end{tabular}

**. Correlation is significant at the 0.01 level (2-tailed)

The above table represents the Pearson correlations coefficient among various variables. From the above, it is evident that there is a very high correlation between prospects of Jharkhand Tourism and two independent variables Economic development and Infrastructure development.

\section{Regression Model}

Dependent variable $\mathrm{Y}=$ Prospects of Jharkhand Tourism

Independent variables:

$\mathrm{X}_{1}=$ Economic Development

$\mathrm{X}_{2}=$ Socio-Cultural

$\mathrm{X}_{3}=$ Cost of Living

$\mathrm{X}_{4}=$ Infrastructure Development

$\mathrm{X}_{5}=$ Environmental Quality

Input Dataset consisting of 300 observations (50 each from 6 different districts)

Looking at correlation coefficient from Table No. 3 it was found that variable Infrastructure development and Economic development are strongly correlated with prospects of Jharkhand Tourism.

Regression equation obtained from the Analysis are:

Prospects of Jharkhand Tourism $=-3.453+0.473$ (Economic Development $)+0.075$ (Socio Cultural $)+0.035$ (Cost of Living) +0.511 (Infrastructure Development) -0.013 (Environmental Quality).

$\mathrm{Y}=-3.453+0.473 \mathrm{X}_{1}+0.075 \mathrm{X}_{2}+0.035 \mathrm{X}_{3}+0.511 \mathrm{X}_{4}-0.013 \mathrm{X}_{5}$

Table 4

Descriptive Statistics

\begin{tabular}{lrrr}
\hline & Mean & Std. Deviation & \multicolumn{1}{l}{ N } \\
\hline Prospects of Jharkhand Tourist & .50 & .720 & 300 \\
Economic Development & 3.6200 & .71892 & 300 \\
Socio Cultural & 3.4643 & .72892 & 300 \\
Cost of Living & 3.6037 & .76320 & 300 \\
Infrastructure Development & 3.7153 & .62527 & 300 \\
Environmental Quality & 3.4980 & .62004 & 300 \\
\hline
\end{tabular}


Table 5

Variables Entered/Removed ${ }^{\text {a }}$

\begin{tabular}{rlrl}
\hline Model & $\begin{array}{l}\text { Variables } \\
\text { Entered }\end{array}$ & $\begin{array}{l}\text { Variables } \\
\text { Removed }\end{array}$ & Method \\
\hline \multirow{3}{*}{1} & Environmental & \\
Quality, Socio- & & . Enter \\
& Cultural, Cost of & \\
& Living, & \\
& Economic & \\
& Development, & \\
& Infrastructure \\
& Development ${ }^{\text {b }}$ & \\
\hline
\end{tabular}

a. Dependent Variable: Prospects of Jharkhand Tourist

b. All requested variables entered.

Table 6

Model Summary ${ }^{\mathrm{b}}$

\begin{tabular}{|c|c|c|c|c|c|c|c|c|c|}
\hline \multirow[b]{2}{*}{ Model R } & \multirow[b]{2}{*}{ R Square } & \multirow[b]{2}{*}{$\begin{array}{l}\text { Adjusted R } \\
\text { Square }\end{array}$} & \multirow[b]{2}{*}{$\begin{array}{l}\text { Std. The error } \\
\text { of the Estimate }\end{array}$} & \multicolumn{5}{|c|}{ Change Statistics } & \multirow[b]{2}{*}{$\begin{array}{l}\text {-Durbin- } \\
\text { Watson }\end{array}$} \\
\hline & & & & $\begin{array}{l}\text { R Square } \\
\text { Change }\end{array}$ & F Change & df1 & df2 & $\begin{array}{l}\text { Sig. F } \\
\text { Change }\end{array}$ & \\
\hline 1 & .836 & .833 & .294 & .836 & 299.461 & 5 & 294 & .000 & 2.569 \\
\hline
\end{tabular}

a. Predictors: (Constant), Environmental Quality, Socio-Cultural, Cost of Living, Economic Development, Infrastructure Development

b. Dependent Variable: Prospects of Jharkhand Tourist

Table 7

ANOVA a

\begin{tabular}{lllllll}
\hline Model & & Sum of Squares & df & Mean Square & F & Sig. \\
\hline \multirow{2}{*}{1} & Regression & 129.560 & 5 & 25.912 & 299.461 & $.000^{\mathrm{b}}$ \\
& Residual & 25.440 & 294 & .087 & & \\
& Total & 155.000 & 299 & & & \\
\hline
\end{tabular}

a. Dependent Variable: Prospects of Jharkhand Tourist

b. Predictors: (Constant), Environmental Quality, Socio-Cultural, Cost of Living, Economic

Development, Infrastructure Development

From the Model Summary and Anova Table, it is found that Regression Model is statistically significant.

The $\mathrm{R}^{2}$ (Coefficient of determination) value is 0.836 and adjusted $\mathrm{R}^{2}$ value is 0.833 , this indicates that $83 \%$ of the regression model is explained by all the 5 independent variables taken together. Also, the impact of multicollinearity on regression model is not significant because the difference between $\mathrm{R}^{2}$ value and adjusted $\mathrm{R}^{2}$ value is negligible.

Effect of multicollinearity is also obtained from collinearity statistics test (variance inflation factor, VIF) which is evident from Table 8. From the table, it is found that VIF of all the parameters are less than 5 which implies that impact of multicollinearity on regression model is not severe.

Application of t-test as indicated in Table No.8 for the significance of individual independent variable indicates that Economic development, Infrastructure development, Socio-Cultural as well as a constant term are statistically significant. The only Cost of living and Environmental quality are not significant. 
Table 8

Coefficients

\begin{tabular}{|c|c|c|c|c|c|c|c|c|c|c|c|}
\hline \multirow{2}{*}{\multicolumn{2}{|c|}{ Model }} & \multicolumn{2}{|c|}{$\begin{array}{c}\text { Unstandardized } \\
\text { Coefficients }\end{array}$} & \multirow{2}{*}{$\begin{array}{l}\text { Standardized } \\
\text { Coefficients } \\
\text { Beta }\end{array}$} & \multirow{2}{*}{$\mathrm{t}$} & \multirow{2}{*}{ Sig. } & \multicolumn{3}{|c|}{ Correlations } & \multicolumn{2}{|c|}{$\begin{array}{c}\text { Collinearity } \\
\text { Statistics }\end{array}$} \\
\hline & & B & Std. Error & & & & $\begin{array}{l}\text { Zero- } \\
\text { order }\end{array}$ & Partial & Part & Tolerance & VIF \\
\hline \multirow{6}{*}{1} & (Constant) & -3.453 & .133 & & -25.987 & .000 & & & & & \\
\hline & $\begin{array}{l}\text { Economic } \\
\text { Development }\end{array}$ & .473 & .038 & .473 & 12.331 & .000 & .850 & .584 & .291 & .380 & 2.632 \\
\hline & Socio Cultural & .075 & .029 & .076 & 2.630 & .009 & .544 & .152 & .062 & .666 & 1.502 \\
\hline & Cost of Living & .035 & .029 & .037 & 1.197 & .232 & .451 & .070 & .028 & .595 & 1.681 \\
\hline & $\begin{array}{l}\text { Infrastructure } \\
\text { Development }\end{array}$ & .511 & .048 & .444 & 10.584 & .000 & .853 & .525 & .250 & .318 & 3.149 \\
\hline & $\begin{array}{l}\text { Environmental } \\
\text { Quality }\end{array}$ & -.013 & .029 & -.011 & -.444 & .657 & .201 & -.026 & -.010 & .909 & 1.100 \\
\hline
\end{tabular}

a. Dependent Variable: Prospects of Jharkhand Tourist

It is also evident from above table that all the parameters coefficient of regression model except Environmental Quality has positive impacts on the prospects of Jharkhand Tourism. The parameter coefficient of Infrastructure Development and Economic Development possess high numeric values as compared to three Tourism traits.

Durbin-Watson test from Table No.6 shows that effect of autocorrelation on the regression is very insignificant (value of Durbin-Watson test is 2.569 which indicates that serial correlation is not present).

\section{Forward Stepwise Regression Model}

The above regression model undertakes one variable at a time, starting with one which explains most of the variation in the dependent variable (the prospect of Jharkhand Tourism) and adding one more independent variable to it, reassessing the model to see that both variables form a good model.

Results below show that only three variables (Infrastructure Development, Economic Development, and SocioCultural) are taken up in depicting the regression model. Again, it is evident that two most significant variable namely Infrastructure Development and Economic Development together explain about $83 \%$ of the variation independent variables (prospects of Jharkhand Tourism).

Prospects of Jharkhand Tourism $=-3.456+0.459$ (Economic Development $)+0.540$ (Infrastructure Development $)+$ 0.084 (Socio Cultural)

$\mathrm{Y}=-3.456+0.459 \mathrm{X}_{1}+0.084 \mathrm{X}_{2}+0.540 \mathrm{X}_{4}$

From the Model Summary and Anova Table, it is found that Regression Model is statistically significant.

The $\mathrm{R}^{2}$ (Coefficient of determination) value is 0.835 and adjusted $\mathrm{R}^{2}$ value is 0.833 , this indicates that $84 \%$ of the regression model is explained by all the 3 independent variables taken together. Also, the impact of multicollinearity on regression model is not significant because the difference between $\mathrm{R}^{2}$ value and adjusted $\mathrm{R}^{2}$ value is negligible.

Effect of multicollinearity is also obtained from collinearity statistics test (variance inflation factor, VIF) which is evident from Table No.11. From the table, it is found that VIF of all the parameters are less than 5 which implies that impact of multicollinearity on regression model is not severe.

Application of t-test as indicated in Table No.11 as implicit considering forward regression model only significant independent variables were considered which are Economic development, Infrastructure development, and SocioCultural.

It is also evident from above table that all the parameters coefficient of regression model has positive impacts on the prospects of Jharkhand Tourism. The parameter coefficient of Infrastructure Development and Economic Development possess high numeric values as compared to three Tourism traits.

Durbin-Watson test from Table No.10 shows that effect of autocorrelation on the regression is very insignificant (value of Durbin-Watson test is 2.642 which indicates that serial correlation is not present). 
Table 9

Variables Entered/Removed ${ }^{\text {a }}$

\begin{tabular}{clll}
\hline Model & Variables Entered & $\begin{array}{l}\text { Variables } \\
\text { Removed }\end{array}$ & Method \\
\hline 1 & Infrastructure Development &. & Forward (Criterion: Probability-of-F-to-enter $<=.050)$ \\
2 & Economic Development &. & Forward (Criterion: Probability-of-F-to-enter $<=.050)$ \\
3 & Socio-Cultural &. & Forward (Criterion: Probability-of-F-to-enter $<=.050)$ \\
\hline
\end{tabular}

a. Dependent Variable: Prospects of Jharkhand Tourist

Table 10

Model Summary

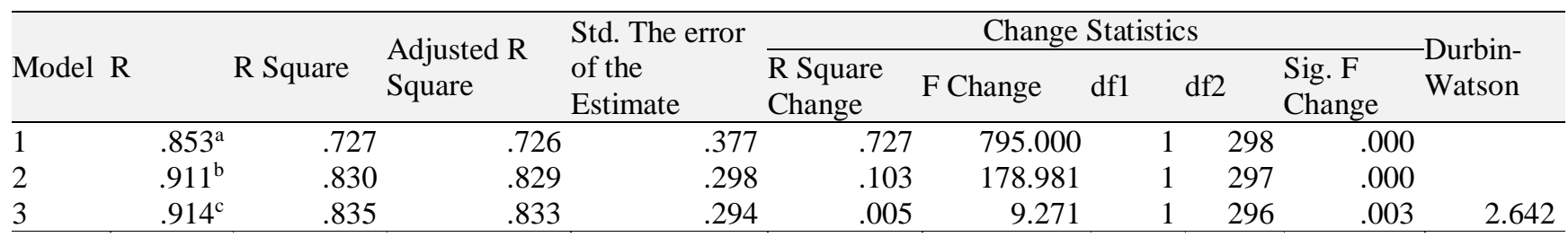

a. Predictors: (Constant), Infrastructure Development

b. Predictors: (Constant), Infrastructure Development, Economic Development

c. Predictors: (Constant), Infrastructure Development, Economic Development, Socio Cultural

d. Dependent Variable: Prospects of Jharkhand Tourist

Table 11

Coefficients

\begin{tabular}{|c|c|c|c|c|c|c|c|c|c|c|c|}
\hline \multirow{2}{*}{\multicolumn{2}{|c|}{ Model }} & \multicolumn{2}{|c|}{$\begin{array}{c}\text { Unstandardized } \\
\text { Coefficients }\end{array}$} & \multirow{2}{*}{$\begin{array}{l}\text { Standardized } \\
\text { Coefficients } \\
\text { Beta }\end{array}$} & & \multirow{2}{*}{ Sig. } & \multicolumn{3}{|c|}{ Correlations } & \multicolumn{2}{|c|}{$\begin{array}{c}\text { Collinearity } \\
\text { Statistics }\end{array}$} \\
\hline & & B & $\begin{array}{l}\text { Std. } \\
\text { Error }\end{array}$ & & & & $\begin{array}{l}\text { Zero- } \\
\text { order }\end{array}$ & Partial & Part & Tolerance & VIF \\
\hline \multirow{3}{*}{1} & (Constant) & -3.149 & .131 & & -23.996 & .000 & & & & & \\
\hline & Infrastructure Development & .982 & .035 & .853 & 28.196 & .000 & .853 & .853 & .853 & 1.000 & 1.000 \\
\hline & (Constant) & -3.357 & .105 & & -31.973 & .000 & & & & & \\
\hline \multirow[t]{3}{*}{2} & Infrastructure Development & .569 & .041 & .494 & 13.728 & .000 & .853 & .623 & .329 & .443 & 2.258 \\
\hline & Economic Development & .482 & .036 & .481 & 13.378 & .000 & .850 & .613 & .320 & .443 & 2.258 \\
\hline & (Constant) & -3.456 & .109 & & -31.830 & .000 & & & & & \\
\hline \multirow{3}{*}{3} & Infrastructure Development & .540 & .042 & .469 & 12.871 & .000 & .853 & .599 & .304 & .420 & 2.379 \\
\hline & Economic Development & .459 & .036 & .458 & 12.629 & .000 & .850 & .592 & .298 & .424 & 2.361 \\
\hline & Socio Cultural & .084 & .028 & .085 & 3.045 & .003 & .544 & .174 & .072 & .719 & 1.391 \\
\hline
\end{tabular}

a. Dependent Variable: Prospects of Jharkhand Tourist

Table 12

Excluded Variables ${ }^{\text {a }}$

\begin{tabular}{|c|c|c|c|c|c|c|c|c|}
\hline \multirow{2}{*}{\multicolumn{2}{|c|}{ Model }} & \multirow[b]{2}{*}{ Beta In } & \multirow[b]{2}{*}{$\mathrm{t}$} & \multirow[b]{2}{*}{ Sig. } & \multirow[b]{2}{*}{$\begin{array}{l}\text { Partial } \\
\text { Correlation }\end{array}$} & \multicolumn{3}{|c|}{ Collinearity Statistics } \\
\hline & & & & & & Tolerance & VIF & $\begin{array}{l}\text { Minimum } \\
\text { Tolerance }\end{array}$ \\
\hline \multirow{4}{*}{1} & Economic Development & $.481^{\mathrm{b}}$ & 13.378 & .000 & .613 & .443 & 2.258 & .443 \\
\hline & Socio Cultural & $.158^{\mathrm{b}}$ & 4.691 & .000 & .263 & .752 & 1.330 & .752 \\
\hline & Cost of Living & $-.029^{b}$ & -.793 & .428 & -.046 & .695 & 1.438 & .695 \\
\hline & Environmental Quality & $.050^{\mathrm{b}}$ & 1.624 & .105 & .094 & .968 & 1.033 & .968 \\
\hline \multirow{2}{*}{2} & Socio Cultural & $.085^{\mathrm{c}}$ & 3.045 & .003 & .174 & .719 & 1.391 & .420 \\
\hline & Cost of Living & $.056^{\mathrm{c}}$ & 1.903 & .058 & .110 & .664 & 1.507 & .322 \\
\hline
\end{tabular}


14

\begin{tabular}{|c|c|c|c|c|c|c|}
\hline Environmental Quality & $.000^{\mathrm{c}}$ & -.003 & .997 & .000 & .945 & 1.058 \\
\hline Cost of Living & $.034^{\mathrm{d}}$ & 1.137 & .256 & .066 & .615 & 1.626 \\
\hline Environmental Quality & $-.006^{\mathrm{d}}$ & -.232 & .817 & -.013 & .940 & 1.064 \\
\hline
\end{tabular}

a. Dependent Variable: Prospects of Jharkhand Tourist

b. Predictors in the Model: (Constant), Infrastructure Development

c. Predictors in the Model: (Constant), Infrastructure Development, Economic Development

d. Predictors in the Model: (Constant), Infrastructure Development, Economic Development, Socio Cultural

\section{Application of Chi Square Test}

$\mathrm{H}_{0}$ : Prospects of Jharkhand Tourism is independent of Tourist circuits.

$\mathrm{H}_{1}$ : Prospects of Jharkhand Tourism is dependent on Tourist circuits.

Table 13

Prospects of Jharkhand Tourist * District Crosstabulation

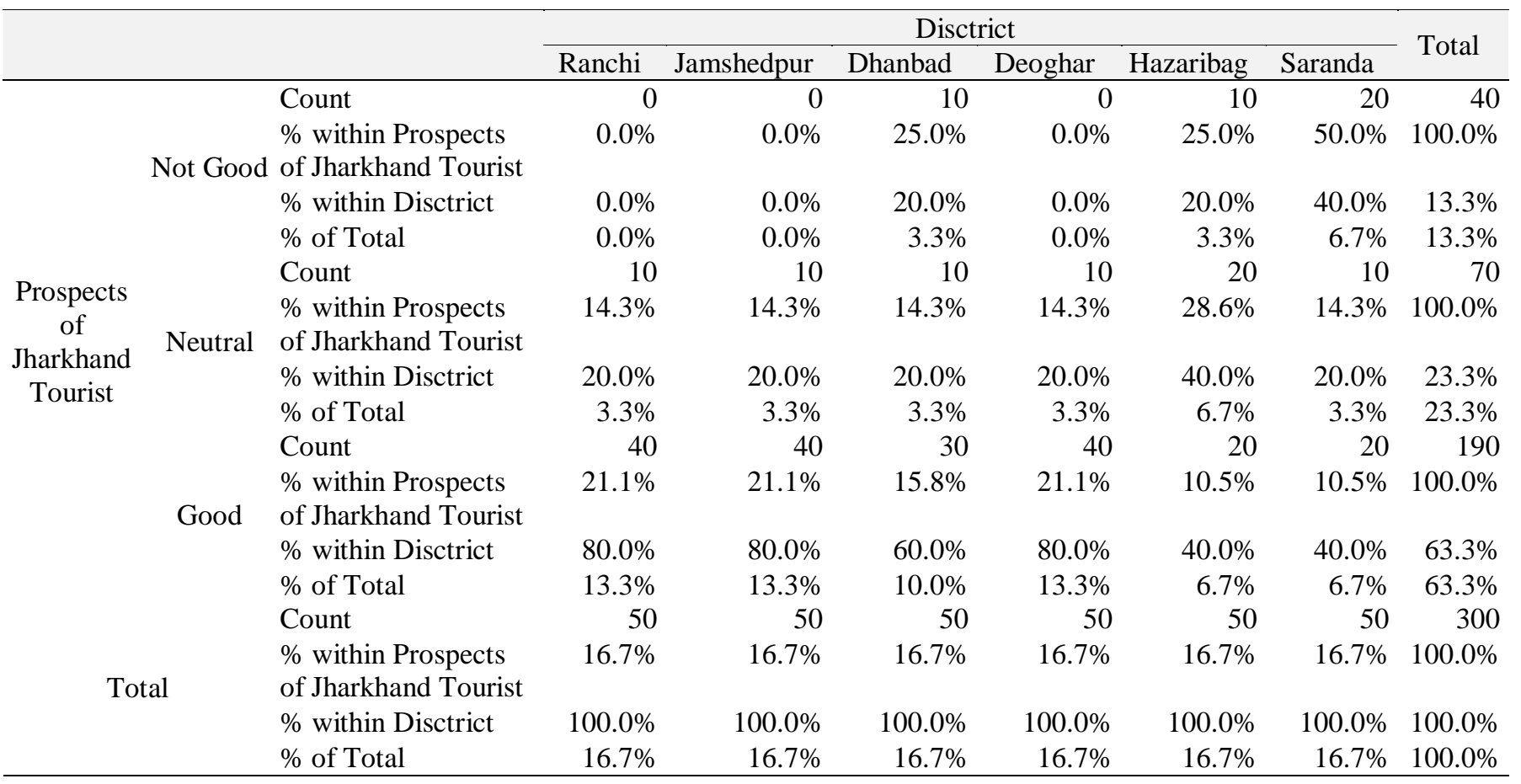

Table 14

Chi-Square Tests

\begin{tabular}{llll}
\hline & Value & df & $\begin{array}{l}\text { Asymp. Sig. (2- } \\
\text { sided) }\end{array}$ \\
\hline Pearson Chi-Square & $72.406^{\mathrm{a}}$ & 10 & .000 \\
Likelihood Ratio & 82.369 & 10 & .000 \\
Linear-by-Linear Association & 40.179 & 1 & .000 \\
N of Valid Cases & 300 & & \\
\hline
\end{tabular}

a. 0 cells $(.0 \%)$ have expected count less than 5 . The minimum expected count is 6.67 .

Asymptote test from the above table indicates that prospects of Jharkhand Tourism are not independent on the Tourists circuits. 
From the Chi-Square test, it is evident that the null hypothesis is rejected and the alternate hypothesis $\mathrm{H}_{1}$ accepted which indicates that prospects of Jharkhand Tourism are dependent on Tourists circuit.

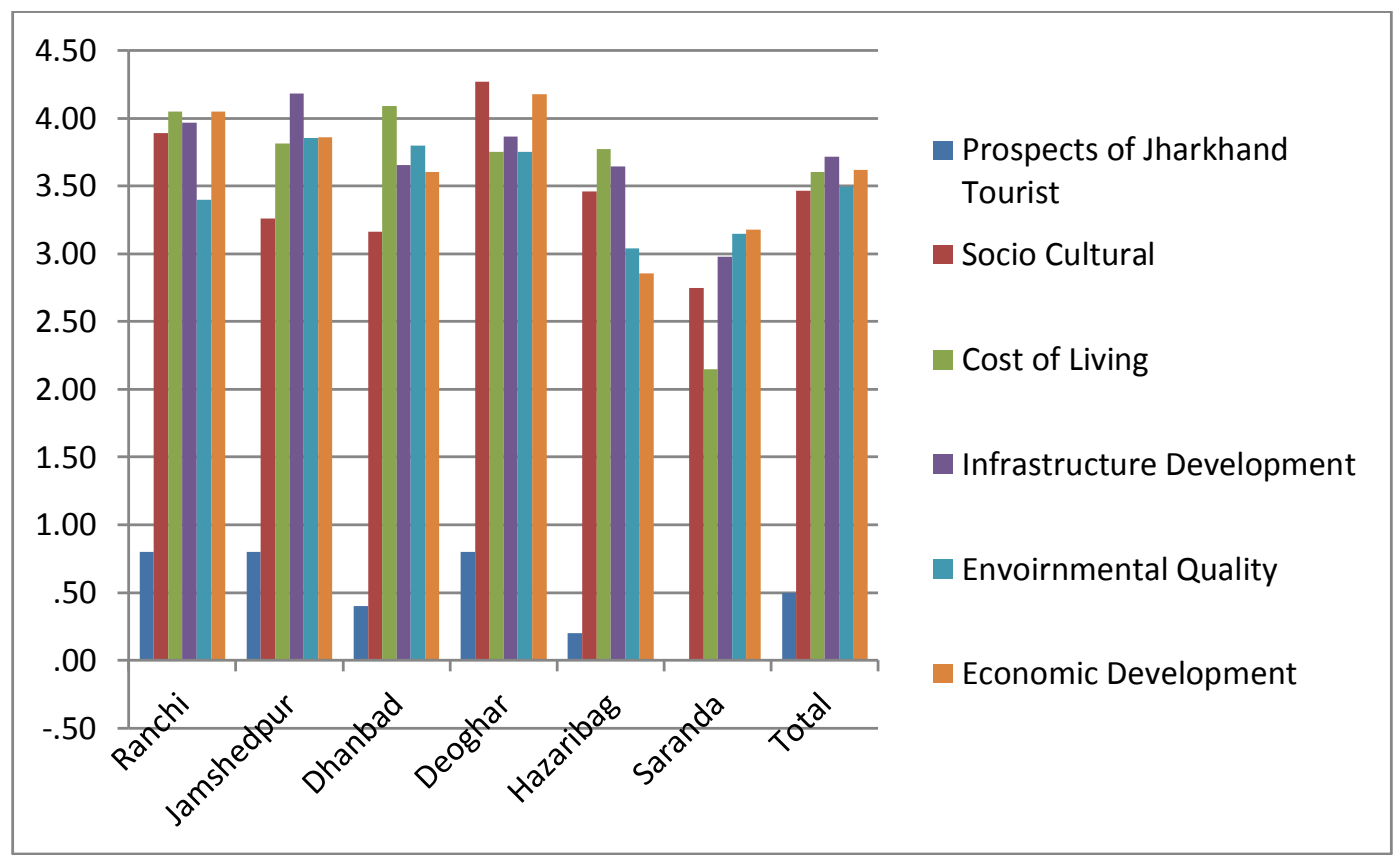

Figure 1. Mean Responses of Residents of Different Districts

\section{Conclusion}

From the above study, it is apparent that Jharkhand has developed a considerable image as a tourism destination. It offers all the popular types of tourism, however, few categories of tourism need more awareness and marketing. The study analyses that prospects of Jharkhand tourism are dependent on Tourism traits identified as Economic Development, Cost of living, Infrastructure Development, Socio-Cultural and Environment. However, the study concludes that the prospects of Jharkhand tourism exist though heavily dependent on Economic and Infrastructure Development. Jharkhand tourism is a portfolio of tourism delight by its composition of 24 districts having demographic uniqueness. Nonetheless, Jharkhand tourism is dependent on important Tourists circuits as identified in the study of Ranchi, Hazaribagh, Jamshedpur, Dhanbad, Deoghar and Saranda amongst the 24 districts. Prospects of Saranda Tourism need more emphasis to increase the influx of tourists. The visit to the state is more preferred in the winter season, festival seasons and season favorable for religious tourism. This implies that Jharkhand is gaining a reputation as one of the important tourist destinations in the country. Therefore there is strong need for increasing the facilities, safety, and infrastructure conducive for tourists to enjoy different tourism category available at popular tourist circuits in the state. The implementation of the draft proposed tourism policy of the year 2014 is under the quagmire of political consideration which needs serious efforts in order to promulgate Jharkhand tourism.

\section{Acknowledgements}

The author would like to thank the editor for their valuable time and advice. 


\section{References}

Astawa, I. N., Mantra, I. B. N., \& Widiastuti, I. A. M. S. (2017). Developing Communicative English Language Tests for Tourism Vocational High School Students. International Journal of Social Sciences and Humanities (IJSSH), 1(2), 58-64.

Boyington, P. (1912). the entire wiki with video and photo galleries find something interesting to watch in seconds. Coeur.

Brata, I. B., \& Pemayun, A. G. P. (2018). Human Resource Competency Tourism Bali together with ASEAN Economic Community. International Research Journal of Management, IT and Social Sciences (IRJMIS), 5(2), 186-194.

Bull, A. (1995). Economics of travel and tourism (No. Ed. 2). Longman Australia Pty Ltd.

Dickinson, J., \& Lumsdon, L. (2010). Slow travel and tourism. Routledge.

Goodwin, H. (2006). Measuring and reporting the impact of tourism on poverty, Cutting edge research in tourism: New directions, challenges, and applications. UK: University of Surrey.

Hall, C. M. (1995). Tourism, Ecotourism and Protected Areas. Gland: IUCN Publication. p150.

Harrison, D. (2001). Tourism in small islands and microstates.

Kumar, N. (1996). Tourism and economic development. APH Publishing Corporation.

Lama, B. (2006). Community Bases Tourism for Conservation \& Women's Development. Nepal: The Mountain Institute.

Pearce, D. G. (1987). Spatial patterns of package tourism in Europe. Annals of tourism research, 14(2), 183-201.

Robinson, H. (1996). Geography of Tourism. John Street, London: MacDonald \& Evence Ltd. 8.

Romila, C. (2004). Economics of Tourism and development.

Schrand, A. (1998). Social indicators of sustainable tourism. na.

Schubert, S. F., Brida, J. G., \& Risso, W. A. (2011). The impacts of international tourism demand on economic growth of small economies dependent on tourism. Tourism Management, 32(2), 377-385.

Sharma, K. L. (1975). Entrepreneurial Performance in Role Performance.

Sharma, P. (1995). Tourism for Local Community Development in Mountain Areas. NORAD: ICIMOD.

Wisudawati, N. N. S., \& Maheswari, A. I. A. (2018). Potential of Silver Craft Product through to Community-Based for Tourism Sustainability in Celuk Village. International Research Journal of Management, IT and Social Sciences (IRJMIS), 5(1), 9-15. 
Appendix

\section{QUESTIONNAIRE SURVEY}

Resident's Response about the Impact on Economic Development by Jharkhand Tourism (JT):

\begin{tabular}{|c|c|c|c|c|c|c|}
\hline S. No. & Development Criterion & $\begin{array}{c}\text { Very } \\
\text { wrong }\end{array}$ & Wrong & $\begin{array}{l}\text { No idea } \\
\text { (Not } \\
\text { certain) }\end{array}$ & True & $\begin{array}{l}\text { Very } \\
\text { true }\end{array}$ \\
\hline 1. & $\begin{array}{l}\text { JT have created employment } \\
\text { opportunity for locals }\end{array}$ & & & & & \\
\hline 2. & $\begin{array}{l}\text { JT have created more seasonal } \\
\text { jobs }\end{array}$ & & & & & \\
\hline 3. & $\begin{array}{l}\text { JT have made livelihood of } \\
\text { few people depended on } \\
\text { Tourism }\end{array}$ & & & & & \\
\hline 4. & $\begin{array}{l}\text { JT have increased the income } \\
\text { of local residents }\end{array}$ & & & & & \\
\hline 5. & $\begin{array}{l}\text { JT have increased the business } \\
\text { of existing local vendors }\end{array}$ & & & & & \\
\hline 6. & $\begin{array}{l}\text { JT have encouraged the } \\
\text { optimal use of resources }\end{array}$ & & & & & \\
\hline 7. & $\begin{array}{l}\text { JT have promulgated ancillary } \\
\text { enterprises }\end{array}$ & & & & & \\
\hline 8. & $\begin{array}{l}\text { JT have absorbed migrated } \\
\text { labour from other occupations }\end{array}$ & & & & & \\
\hline 9. & $\begin{array}{l}\text { JT have supplemented the } \\
\text { Rural economy }\end{array}$ & & & & & \\
\hline
\end{tabular}


Resident's Response about the Impact on Socio-Cultural Effect by Jharkhand Tourism (JT):

\begin{tabular}{|c|c|c|c|c|c|c|}
\hline S. No. & Development Criterion & $\begin{array}{l}\text { Very } \\
\text { wrong }\end{array}$ & Wrong & $\begin{array}{l}\text { No idea } \\
\text { (Not } \\
\text { certain) }\end{array}$ & True & $\begin{array}{l}\text { Very } \\
\text { true }\end{array}$ \\
\hline 1. & $\begin{array}{l}\text { JT have increased the } \\
\text { Availability of Recreational } \\
\text { Facilities }\end{array}$ & & & & & \\
\hline 2. & $\begin{array}{l}\text { JT have nurtured the local } \\
\text { tribal customs \& culture }\end{array}$ & & & & & \\
\hline 3. & $\begin{array}{l}\text { JT have raised the opportunity } \\
\text { of shopping }\end{array}$ & & & & & \\
\hline 4. & $\begin{array}{l}\text { JT have increased the } \\
\text { Religious Activities }\end{array}$ & & & & & \\
\hline 5. & $\begin{array}{l}\text { JT have helped in Renovation } \\
\text { and Maint. of building and } \\
\text { Monuments }\end{array}$ & & & & & \\
\hline 6. & $\begin{array}{l}\text { JT have affected the peace of } \\
\text { the Area }\end{array}$ & & & & & \\
\hline 7. & $\begin{array}{l}\text { JT have increased the Literacy } \\
\text { Rate }\end{array}$ & & & & & \\
\hline 8. & $\begin{array}{l}\text { JT have affected the religious } \\
\text { faith in local Deities }\end{array}$ & & & & & \\
\hline 9. & $\begin{array}{l}\text { JT have complimented } \\
\text { Religious Pilgrimage }\end{array}$ & & & & & \\
\hline 10. & $\begin{array}{l}\text { JT have increased the } \\
\text { Awareness of Locals about the } \\
\text { outer World }\end{array}$ & & & & & \\
\hline 11. & $\begin{array}{l}\text { JT have increased the Crowd } \\
\text { more than the carrying } \\
\text { capacity }\end{array}$ & & & & & \\
\hline 12. & $\begin{array}{l}\text { JT have supplemented the } \\
\text { Social Evils }\end{array}$ & & & & & \\
\hline 13. & $\begin{array}{l}\text { JT have somewhat effected the } \\
\text { uniqueness of Cultural Identity }\end{array}$ & & & & & \\
\hline 14. & $\begin{array}{l}\text { JT have supplemented Law } \\
\text { and Order Problem }\end{array}$ & & & & & \\
\hline 15. & $\begin{array}{l}\text { JT have affected the local } \\
\text { culture and values }\end{array}$ & & & & & \\
\hline
\end{tabular}


Resident's Response about the Impact on Cost of Living by Jharkhand Tourism (JT):

\begin{tabular}{|c|l|c|c|c|c|c|}
\hline S. No. & \multicolumn{1}{|c|}{ Development Criterion } & $\begin{array}{c}\text { Very } \\
\text { wrong }\end{array}$ & Wrong & $\begin{array}{c}\text { No idea } \\
\text { (Not } \\
\text { certain) }\end{array}$ & True & $\begin{array}{c}\text { Very } \\
\text { true }\end{array}$ \\
\hline 1. & $\begin{array}{l}\text { JT have Inflated the Price of } \\
\text { basic Goods/Services }\end{array}$ & & & & & \\
\hline 2. & $\begin{array}{l}\text { JT have appreciated the cost of } \\
\text { land and Housing facility }\end{array}$ & & & & & \\
\hline 3. & $\begin{array}{l}\text { JT have increased the rental } \\
\text { value of lodging and } \\
\text { establishing shops }\end{array}$ & & & & & \\
\hline 4. & $\begin{array}{l}\text { JT have Enriched the living } \\
\text { standard of masses }\end{array}$ & & & & & \\
\hline
\end{tabular}


Resident's Response about the Impact on Infrastructure Development by Jharkhand Tourism (JT):

\begin{tabular}{|c|c|c|c|c|c|c|}
\hline S. No. & Development Criterion & $\begin{array}{c}\text { Very } \\
\text { wrong }\end{array}$ & Wrong & $\begin{array}{l}\text { No idea } \\
\text { (Not } \\
\text { certain) }\end{array}$ & True & $\begin{array}{l}\text { Very } \\
\text { true }\end{array}$ \\
\hline 1. & $\begin{array}{l}\text { JT have developed the } \\
\text { highway and improvised road } \\
\text { conditions of major Tourist } \\
\text { circuits }\end{array}$ & & & & & \\
\hline 2. & $\begin{array}{l}\text { JT have supplemented Art \& } \\
\text { Craft Industries promoting } \\
\text { Jharkhand craft / Handloom } \\
\text { Industries }\end{array}$ & & & & & \\
\hline 3. & $\begin{array}{l}\text { JT have improvised the } \\
\text { transportation network }\end{array}$ & & & & & \\
\hline 4. & $\begin{array}{l}\text { JT have improvised the } \\
\text { communication network }\end{array}$ & & & & & \\
\hline 5. & $\begin{array}{l}\text { JT have supplemented the } \\
\text { Infrastructure } \\
\text { Development of major Tourist } \\
\text { circuits }\end{array}$ & & & & & \\
\hline 6. & $\begin{array}{l}\text { JT have improvised supply of } \\
\text { electricity, } \\
\text { water and sanitation facilities } \\
\text { of major Tourist circuits }\end{array}$ & & & & & \\
\hline
\end{tabular}


Resident's Response about the Impact on Environment Quality by Jharkhand Tourism (JT):

\begin{tabular}{|c|l|l|l|l|l|l|}
\hline S. No. & \multicolumn{1}{|c|}{ Development Criterion } & $\begin{array}{c}\text { Very } \\
\text { wrong }\end{array}$ & Wrong & $\begin{array}{c}\text { No idea } \\
\text { (Not } \\
\text { certain) }\end{array}$ & True & $\begin{array}{c}\text { Very } \\
\text { true }\end{array}$ \\
\hline 1. & $\begin{array}{l}\text { JT have affected the natural } \\
\text { scenic Beauty }\end{array}$ & & & & \\
\hline 2. & $\begin{array}{l}\text { JT have promulgated } \\
\text { deforestation }\end{array}$ & $\begin{array}{l}\text { JT have Increased the air \& } \\
\text { noise pollution }\end{array}$ & & & & \\
\hline 3. & $\begin{array}{l}\text { JT have supplemented to } \\
\text { water scarcity and water } \\
\text { pollution }\end{array}$ & & & & \\
\hline
\end{tabular}

